OPEN ACCESS

Edited by:

Anne Bernhard,

Connecticut College, USA

Reviewed by:

Matthew Wallenstein,

Colorado State University, USA

Nathan Basiliko,

Laurentian University, Canada

*Correspondence:

Marco J. L. Coolen,

Western Australia Organic and Isotope Geochemistry Centre, Department of

Chemistry, Curtin University, GPO Box

U1987, Perth, WA 6845, Australia

marco.coolen@curtin.edu.au

${ }^{t}$ These authors have contributed equally to this work.

Specialty section:

This article was submitted to Terrestrial Microbiology, a section of the journal Frontiers in Microbiology

Received: 06 January 2015

Accepted: 24 February 2015

Published: 16 March 2015

Citation:

Coolen MJL and Orsi WD (2015) The

transcriptional response of microbial

communities in thawing Alaskan

permafrost soils.

Front. Microbiol. 6:197.

doi: 10.3389/fmicb.2015.00197

\section{The transcriptional response of microbial communities in thawing Alaskan permafrost soils}

\author{
Marco J. L. Coolen ${ }^{1,2 *+}$ and William D. Orsi ${ }^{1 \dagger}$ \\ ${ }^{1}$ Marine Chemistry and Geochemistry Department, Woods Hole Oceanographic Institution, Woods Hole, MA, USA, ${ }^{2}$ Western \\ Australia Organic and Isotope Geochemistry Centre, Department of Chemistry, Curtin University, Perth, WA, Australia
}

Thawing of permafrost soils is expected to stimulate microbial decomposition and respiration of sequestered carbon. This could, in turn, increase atmospheric concentrations of greenhouse gasses, such as carbon dioxide and methane, and create a positive feedback to climate warming. Recent metagenomic studies suggest that permafrost has a large metabolic potential for carbon processing, including pathways for fermentation and methanogenesis. Here, we performed a pilot study using ultrahigh throughput Illumina HiSeq sequencing of reverse transcribed messenger RNA to obtain a detailed overview of active metabolic pathways and responsible organisms in up to $70 \mathrm{~cm}$ deep permafrost soils at a moist acidic tundra location in Arctic Alaska. The transcriptional response of the permafrost microbial community was compared before and after 11 days of thaw. In general, the transcriptional profile under frozen conditions suggests a dominance of stress responses, survival strategies, and maintenance processes, whereas upon thaw a rapid enzymatic response to decomposing soil organic matter (SOM) was observed. Bacteroidetes, Firmicutes, ascomycete fungi, and methanogens were responsible for largest transcriptional response upon thaw. Transcripts indicative of heterotrophic methanogenic pathways utilizing acetate, methanol, and methylamine were found predominantly in the permafrost table after thaw. Furthermore, transcripts involved in acetogenesis were expressed exclusively after thaw suggesting that acetogenic bacteria are a potential source of acetate for acetoclastic methanogenesis in freshly thawed permafrost. Metatranscriptomics is shown here to be a useful approach for inferring the activity of permafrost microbes that has potential to improve our understanding of permafrost SOM bioavailability and biogeochemical mechanisms contributing to greenhouse gas emissions as a result of permafrost thaw.

Keywords: permafrost, metatranscriptomics, hydrolysis of biopolymers, acetoclastic methanogenesis, biofilm formation, DNA repair, cellular defense mechanisms

\section{Introduction}

The northern permafrost region contains $\sim 1672$ gigatonnes $(\mathrm{Gt})$ of organic carbon, nearly twice the amount of atmospheric carbon. Roughly $1470 \mathrm{Gt}$ or $88 \%$ of this carbon occurs in perennially frozen soils and deposits (Tarnocai et al., 2009). The majority of permafrost organic matter is derived from (partially decomposed) plant material and was buried by dust deposition, sedimentation in flood plains and peat development on time scales of decades to millennia 
(Zimov et al., 2006; Schuur et al., 2008). Permafrost is overlain by a soil horizon that varies in thickness from a few centimeters to several meters, which experiences seasonal freeze-thaw cycles (i.e., the active layer). Owing to atmospheric warming, the depth of the active layer has been increasing in many locations over the past few decades, resulting in a subsequent decline in the underlying permafrost (Kane et al., 1991; Anisimov et al., 1999; Jorgenson et al., 2001; Zhang et al., 2005; Pautler et al., 2010). This warming-induced thickening of the active layer is expected to enhance microbially mediated soil organic matter (SOM) decomposition, and release of carbon from the upper permafrost to the atmosphere (Dutta et al., 2006; Uhlirova et al., 2007; Schuur et al., 2008; Pautler et al., 2010).

Despite subfreezing temperatures and low water availability, permafrost soils up to 3 million years in age harbor a large diversity of bacteria, archaea, and fungi as revealed by sequencing of environmental ribosomal RNA (rRNA) genes (Vishnivetskaya et al., 2006; Liebner et al., 2008; Waldrop et al., 2010; Coolen et al., 2011; Penton et al., 2013; Bakermans et al., 2014; Frank-Fahle et al., 2014; Ganzert et al., 2014). A variety of microbes have retained viability in frozen permafrost over geological time periods and, upon thawing, could renew or accelerate their physiological activity. Many permafrost bacterial isolates are cold-adapted heterotrophs belonging to the phyla Firmicutes, Actinobacteria, Proteobacteria, and Bacteroidetes, while many of the archaeal isolates are methane $\left(\mathrm{CH}_{4}\right)$-producers (methanogens) growing on hydrogen $\left(\mathrm{H}_{2}\right)$ and carbon dioxide $\left(\mathrm{CO}_{2}\right)$ with some species also growing on formate, methanol, or methylamine (Jansson and Tas, 2014 and references therein).

Genomes of bacterial isolates have also revealed insights into strategies for survival in subzero conditions. For example, the genome of the Siberian permafrost isolate Psychrobacter arcticus 273-4 revealed three cold shock proteins, which operate as RNA chaperones that enhance translation processes by eliminating the formation of secondary structures in the messenger RNA (mRNA) (Ayala-Del-Rio et al., 2010). This adaptation is important for $P$. arcticus, and possibly other permafrost bacteria, because subzero temperatures make mRNA more stable and less efficient for translation. Furthermore, P. arcticus uses acetate, which can diffuse into the cell without an energetically costly transport system, as the basis for its biosynthesis and energy metabolism (Ayala-Del-Rio et al., 2010). However, cultured species isolated from permafrost are not necessarily representative of active microbial community in situ, and the ability of some members to form spores (e.g., Firmicutes) may bias phylogenetic representation in culture (Steven et al., 2008; Niederberger et al., 2009).

Recent pioneering metagenomic studies have helped to circumvent some cultivation-biased interpretations of in situ activity, and revealed cultivation-independent insights into which biochemical pathways are present and potentially expressed by permafrost microbiota. Overall, these studies suggest that permafrost microbial communities have a large metabolic potential for carbon processing, including pathways for fermentation, methanogenesis, and nitrogen cycling (Yergeau et al., 2010; Mackelprang et al., 2011; Lipson et al., 2013). However, metagenomic surveys do not provide information on the relative importance and the exact timing of biochemical processes, as cells need to replicate their genomes first to monitor an increase in metabolic potential. In addition, in pristine frozen soil samples it is difficult to distinguish between genes involved in ongoing vs. past microbial processes using DNA-based metagenomic datasets because bacterial, fungal, and plant DNA can be preserved for thousands of years in permafrost soils (Willerslev et al., 2003, 2004; Bellemain et al., 2013). However, metatransciptomic analysis of extremely short-lived mRNA would provide information on microbial activities that occurred in the permafrost soils at the time of sampling.

Here, we performed a pilot study using ultrahigh throughput Illumina HiSeq sequencing of reverse transcribed mRNA (e.g., Orsi et al., 2013; Huang et al., 2014) to obtain a detailed overview of active metabolic pathways and responsible organisms in permafrost soils under pristine frozen conditions and transcriptional responses after 11 days of thaw. The permafrost soil horizons analyzed (up to $70-\mathrm{cm}$-deep) are expected to thaw in the Alaskan Arctic within decades as a result of continuing Arctic warming (Osterkamp, 2007). For our analysis, we were particularly interested in the expression of biochemical pathways that are hypothesized to play an important role in mediating the release of greenhouse gasses from thawing permafrost (e.g., $\mathrm{CO}_{2}$ and $\mathrm{CH}_{4}$ ). We sought to provide the first transcriptional data supporting the hypothesis that microbial degradation of SOM biopolymers leads to increased $\mathrm{CO}_{2}$ production and methanogenesis, and to elucidate the biochemical mechanisms underlying these processes. Parallel geochemical analysis of soil age, carbon and nitrogen content, and lipid biomarkers provided additional information on the sources and composition of permafrost SOM.

\section{Methods}

\section{Site Description and Sample Collection}

Using a SIPRE style auger system (Jon's Machine Shop, Fairbanks, $\mathrm{AK}$ ), a $130-\mathrm{cm}$-long ( $8 \mathrm{~cm}$ diameter) core was recovered on July 27, 2008 from moist acidic tundra (MAT) near the Kuparuk River at the Toolik Long Term Ecological Research (LTER) Field Station, Alaska $\left(68^{\circ} 38^{\prime} 41.455^{\prime \prime} \mathrm{N}: 149^{\circ} 24^{\prime} 09.682^{\prime \prime} \mathrm{W}\right)$ (Coolen et al., 2011). The $\mathrm{pH}$ of the soils was not determined, but a $\mathrm{pH}$ of 3-4 has been reported from comparable North Alaskan MAT soils (Hobbie and Gough, 2004). According to the Alaska Tundra Vegetation Map (Walker and Maier, 2008), the coring location was located in bioclimate subzone $\mathrm{E}$ where mean July temperatures are between 9 and $12^{\circ} \mathrm{C}$ and the tundra vegetation covering the coring site is defined as Class 4.1 Tussock-sedge, dwarf shrub, moss communities on mesic, acidic loess. This is the most common type of vegetation, covering $100,000 \mathrm{~km}^{2}$ or $25 \%$ of the land surface in Arctic Alaska. The thickness of the active layer was $26 \mathrm{~cm}$ at the time of coring. Core sections were described in the field and immediately wrapped in sterile, baked $\left(500^{\circ} \mathrm{C}, 8 \mathrm{~h}\right)$ aluminum foil and kept frozen inside coolers with deeply frozen blue ice packs. At the Toolik Field Station, the melted active layer was kept inside the cooler and the frozen core sections were kept in a freezer at $-5^{\circ} \mathrm{C}$ for up to $2 \mathrm{~h}$ until subsampling was completed: within $2 \mathrm{~h}$ after coring an uncontaminated subsampling surface area was created by removing the outer $1 \mathrm{~cm}$ of frozen 
soil with a sterile knife. Cores were split laterally at the desired depths using a sterilized hammer and a chisel, and subsamples were obtained only from the central part of each interval with sterilized scalpel and tweezers. Thus, the distance between the core liner and subsampled sediment was at least $2 \mathrm{~cm}$ to avoid cross contamination.

Soil samples were collected immediately after coring on July 27,2008 from two active layer horizons $(12 \pm 2$ and $24 \pm 2 \mathrm{~cm})$, and five depth intervals from the underlying permafrost (33.5 $\pm 2,49 \pm 2,68 \pm 2,109 \pm 2$, and $126 \pm 2 \mathrm{~cm}$ ). For lipid analysis, subsamples $(\sim 2 \mathrm{~g})$ were stored frozen at $-20^{\circ} \mathrm{C}$ at the Woods Hole Oceanographic Institution (WHOI) until subsequent lipid extraction. For the subsequent extraction of RNA, $\sim 2 \mathrm{~g}$ aliquots of pristine soils were transferred to $5 \mathrm{ml}$ cryovials and immediately flash frozen in liquid nitrogen. In addition, $20 \mathrm{ml}$ sterile serum flasks were completely filled with soil leaving no headspace, capped airtight, and incubated in the dark at $4^{\circ} \mathrm{C}$. As samples were capped airtight with no headspace, they remained anoxic for the duration of the incubation. Subsamples for RNA extraction were also obtained on the last day of fieldwork (i.e., after 11 days of thaw/incubation). All samples for RNA work were stored in liquid nitrogen during airfreight transport to WHOI and RNA was extracted immediately upon arrival as detailed below.

Radiocarbon dates and bulk geochemical analysis (\%TOC, $\left.\% \mathrm{TN}, \delta^{13} \mathrm{C}, \delta^{15} \mathrm{~N}\right)$ from the exact same intervals were provided previously (Coolen et al., 2011), and compared with the lipid biomarker results from the present study (Figure 1).

\section{Soil Organic Matter Composition}

Lipid biomarker compounds were extracted from soils collected from the 7 depth horizons with a methylene chloride:methanol mixture (9:1, v:v) using a microwave-accelerated reaction system (MARS6) (CEM, Matthews, NC) in which samples were heated at $100^{\circ} \mathrm{C}$ for $15 \mathrm{~min}$ with continuous stirring (Osburn et al., 2011). Following extraction, samples were filtered, dried under $\mathrm{N}_{2}$ gas, and saponified with aqueous $0.5 \mathrm{M}$ sodium hydroxide at $70^{\circ} \mathrm{C}$ for $4 \mathrm{~h}$. Cooled samples were acidified with $3 \mathrm{~N}$ hydrochloric acid $(\mathrm{pH}<3)$ before being extracted 3 times with methyl tert-butyl ether. Subsequently, elemental sulfur was removed by filtering extracts through acid-washed copper. Samples were resuspended in hexane prior to separation of compound classes by solid phase extraction. Discovery DSC-NH2 stationary phase (SigmaAldrich, St. Louis, MO) (1 g) was packed into glass columns and samples were separated into five fractions: F1 $5 \mathrm{ml}$ hexane; F2 $8 \mathrm{ml}$ of 4:1 hexane/methylene chloride; F3 $10 \mathrm{ml}$ of 9:1 methylene chloride/acetone; F4 $15 \mathrm{ml}$ of $2 \%$ formic acid in methylene chloride (Sessions, 2006). Fatty acids (F4) were methylated with acidic methanol $(95: 5$ methanol/ $\mathrm{HCl})$ and heated overnight at $70^{\circ} \mathrm{C}$ to form fatty acids methyl esters. Fractions containing hydrocarbons (F1) and fatty acids (F4) were concentrated and an internal standard was added prior to analysis by gas chromatography-mass spectrometry (GC-MS). One microliter of sample was injected into an Agilent 7890 GC (Agilent Technologies, Santa Clara, CA) with an effluent split $\sim 70: 30$ between a 5975C mass spectrometer and a flame ionizing detector. Peaks were separated on a DB-5 ms column ( $60 \mathrm{~m}$ long, $0.25 \mathrm{~mm}$ ID,
$0.25 \mu \mathrm{m}$ film thickness). Data from hydrocarbon (F1) and fatty acid (F4) fractions are presented here for all samples except the $68 \mathrm{~cm}$ horizon, due to sample loss. From $n$-alkane concentrations (hydrocarbon fraction) we calculated the carbon preference index $(\mathrm{CPI}), \mathrm{P}_{\mathrm{aq}}$ index, and $\mathrm{P}_{\mathrm{wax}}$ index. $\mathrm{CPI}_{\text {alkane }}$ reflects relative inputs of higher plants vs. algae and bacteria since the former have a strong odd/even predominance. Consequently, high $\mathrm{CPI}_{\text {alkane values }}(>5)$ reflect mainly contributions from higher plants (Cranwell et al., 1987).

$$
\begin{aligned}
\mathrm{CPI}_{\text {alkane }}= & \left(\Sigma\left(\mathrm{C}_{21}-\mathrm{C}_{29}\right)_{\text {odd }}+\Sigma\left(\mathrm{C}_{23}-\mathrm{C}_{31}\right)_{\text {odd }}\right) / \\
& \left(2^{*} \Sigma\left(\mathrm{C}_{22}-\mathrm{C}_{30}\right)_{\text {even }}\right)
\end{aligned}
$$

The $\mathrm{P}_{\mathrm{aq}}$ index reflects relative contributions of alkanes from aquatic macrophytes vs. higher plants (Ficken et al., 2000). High $\mathrm{P}_{\mathrm{aq}}$ values $(>0.5)$ indicate inputs from submerged or floating macrophytes and may reflect wet conditions.

$$
\mathrm{P}_{\mathrm{aq}}=\left(\mathrm{C}_{23}+\mathrm{C}_{25}\right) /\left(\mathrm{C}_{23}+\mathrm{C}_{25}+\mathrm{C}_{29}+\mathrm{C}_{31}\right) .
$$

A high $\mathrm{P}_{\text {wax }}$ index value $(>0.7)$ reflects waxy inputs from higher plants and may indicate drier conditions (Zheng et al., 2007):

$$
\mathrm{P}_{\mathrm{wax}}=\left(\mathrm{C}_{27}+\mathrm{C}_{29}+\mathrm{C}_{31}\right) /\left(\mathrm{C}_{23}+\mathrm{C}_{25}+\mathrm{C}_{27}+\mathrm{C}_{29}+\mathrm{C}_{31}\right) .
$$

\section{RNA Extraction and Purification}

Immediately after arrival of the flash frozen soil samples at WHOI, RNA was extracted in triplicate from $\sim 2 \mathrm{~g}$ of soil using the Power Soil ${ }^{\mathrm{TM}}$ Total RNA Isolation kit (MoBio Laboratories, Inc., Carlsbad, CA) following the instructions of the manufacturer. The homogenization step started while the soil was still frozen to minimize degradation of RNA during thawing of the flash frozen soil samples. Standard procedures to further minimize degradation of RNA during the extraction process involved the use of filter tips and certified RNAse free disposables and reagents. Surfaces were cleaned with RNase AWAY ${ }^{\mathrm{TM}}$ (Life Technologies, Grand Island, NY), and all extraction procedures were performed in a HEPA-filtered horizontal laminar flow hood (Labconco, Kansas City, MO) inside a HEPA-filtered and positive-pressured ancient DNA dedicated lab at WHOI to eliminate aerosol contamination by bacterial and fungal cells/spores. DNA was removed using the Turbo DNA-free ${ }^{\circledR}$ kit (Life Technologies), increasing the incubation time to $1 \mathrm{~h}$ to ensure rigorous DNA removal. Extraction blanks were performed (adding sterile water instead of sample) to ensure that aerosolized contaminants did not enter sample and reagent tubes during the extraction process. Short RNA fragments (mostly produced during the extraction protocol) and residual inhibitors (i.e., humics) were removed from the extracted RNA using the MEGA-Clear ${ }^{\circledR}$ RNA Purification Kit (Life Technologies). We followed the protocol all the way through the optional precipitation/concentration step, resuspending the RNA pellet in $10 \mu \mathrm{l}$ of certified RNAse free sterile water (Life Technologies). Prior to cDNA amplification, the removal of contaminating DNA in RNA extracts was confirmed by the absence of visible amplification of SSU rRNA genes after 35 cycles of PCR using the RNA extracts as template, and the quality of the RNA was 

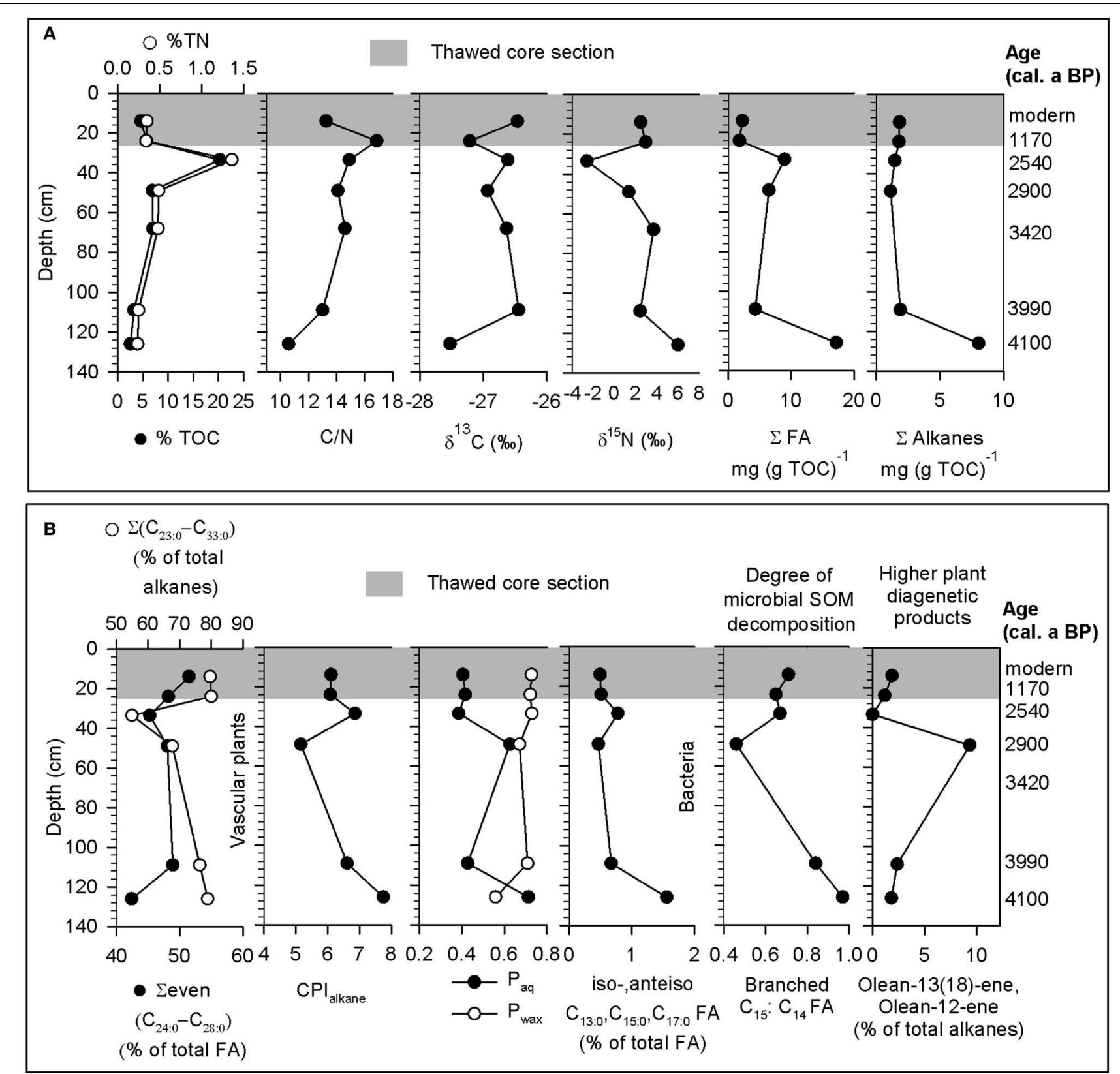

FIGURE 1 | Geochemistry of SOM in the 2 active layer (14 \pm 2 and $24 \pm 2 \mathrm{~cm}$ ) and 5 permafrost soil horizons (33.5 \pm 2 to 126 $\pm 2 \mathrm{~cm}$ ) of core TL08S1C3. (A) Bulk geochemical and stable isotope data and total concentrations of FAs and alkanes. (B) Percent contributions and ratios from lipid sub-classes representing different biological sources. verified by agarose gel electrophoresis. All downstream analyses (cDNA amplification, sequencing, and bioinformatic analyses) described briefly in the following sections followed the protocols developed and reported recently (Orsi et al., 2013, 2015).

\section{Choice of Samples for Subsequent Metatranscriptomic Analysis}

The permafrost soil horizons that were selected for cDNA amplification and Illumina sequencing (up to 70-cm-deep) are expected to thaw in the Alaskan Arctic as a result of continuing Arctic warming (Osterkamp, 2007). High quality RNA was extracted from the permafrost table $(33.5 \pm 2 \mathrm{~cm})$ and from the horizon at $49 \pm 2 \mathrm{~cm}$ before and after thaw. However, only after thaw the soil interval of $68 \pm 2 \mathrm{~cm}$ yielded visible amounts of RNA on gel and subsequent cDNA amplification and Illumina sequencing was therefore not performed on the pristine frozen sample at this depth. The selected permafrost table was thought to contain relatively labile OM (Coolen et al., 2011) whereas the two deeper late-Holocene permafrost intervals (at 49 and $68 \mathrm{~cm}$ depth) potentially contained more recalcitrant SOM. Unfortunately, for budgetary reasons we were not able to sequence the metranscriptomes from the overlying active 
layers. However, parallel analysis of the microbial community composition (ribosomal RNA genes and transcripts) and microbial ectoenzyme activities involved in the hydrolysis of complex soil biopolymers, previously revealed that the most dramatic response in microbial activities and communities occurred in the permafrost intervals after 11 days of thaw while activities and microbial communities underwent little variation in the active layers over the course of incubation (Coolen et al., 2011). For the above reasons, subsequent Illumina sequencing of the reverse transcribed mRNA (this study) was only performed from depth horizons $33.5 \pm 2$ and $49 \pm 2 \mathrm{~cm}$ (before and after 11 days of thaw) and $68 \pm 2 \mathrm{~cm}$ (after 11 days of thaw).

\section{cDNA Amplification and Illumina Sequencing}

Since Illumina HiSeq sequencing was not yet available in 2008, the following steps were performed 5 years after frozen storage $\left(-80^{\circ}\right)$ of the purified RNA: Five nanograms of purified high quality RNA as determined fluorometrically with Quant$\mathrm{iT}^{\mathrm{TM}}$ RiboGreen ${ }^{\circledR} \mathrm{RNA}$ reagent (Life Technologies) was used as template for selective mRNA amplification using the Ovation RNA-Seq v2 System ${ }^{\circledR}$ (NuGEN technologies, San Carlos, CA). We followed the manufacturers instructions for cDNA amplification, and the resulting quantity of cDNA was checked fluorometrically using the Quant-iT ${ }^{\mathrm{TM}}$ PicoGreen ${ }^{\circledR}$ dsDNA Assay Kit (Life Technologies). Quality of the amplified cDNA was checked on a Bioanalyzer (Agilent Technologies, Santa Clara, CA) prior to Illumina ${ }^{\circledR}$ sequencing. cDNA of the triplicate extracts were pooled and Illumina ${ }^{\circledR}$ library preparation and pairedend sequencing was performed at the University of Delaware Sequencing and Genotyping Center (Delaware Biotechnology Institute, Newark DE). We acknowledge that because the original RNA extracts were stored $\sim 5$ years at $-80^{\circ} \mathrm{C}$ prior to metatranscriptome construction, it is possible that some RNA could have been lost or partially degraded.

\section{Quality Control and Assembly}

Quality control of the dataset was performed using FastQC (http://www.bioinformatics.babraham.ac.uk/projects/ fastqc/), with a quality score cutoff of 28 . Approximately 375 million paired-end reads that passed quality control were imported into CLC Genomics Workbench 6.0 ${ }^{\circledR}$ (CLC Bio Inc., Cambridge, $\mathrm{MA}$ ) and assembled using the paired-end Illumina assembler. Contigs were assembled over a range of kmer sizes $(20,50,60,64)$ with a minimum contig size cutoff of 300 nucleotides. The kmer size of 50 resulted in the highest number of contigs and thus these contigs were chosen for use in downstream bioinformatics analyses. To reduce the formation of chimeric assemblies, we used a $2 \times 105$ paired-end sequencing approach on the Illumina HiSeq platform and performed assemblies without scaffolding. Reads were mapped onto the contigs using the read mapping option in CLC Genomics Workbench to retain information on relative abundance of contigs.

\section{Functional Annotation of Contigs}

Contigs were submitted to CAMERA (Community Cyber infrastructure for Advanced Microbial Ecology Research and
Analysis, http://camera.calit2.net/) and assigned to clusters of orthologous gene (COG) families using the Rapid Analysis of Multiple Metagenomes with a Clustering and Annotation Pipeline (RAMMCAP) (Li, 2009) using the 6 reading frame translation option for open reading frame (ORF) prediction and BLASTn for rRNA identifications. The cutoff criterion $E$-value of $10^{-5}$ was used for RPS BLAST searches the COG database. For identification of bacterial and archaeal ORFs, the RAMMCAP analyses were performed using the bacterial and archaeal genetic code (-t 11 in advanced options). For identification of fungal ORFs, additional RAMMCAP analyses were performed using the standard genetic code for eukaryotes and the alternative yeast genetic code $(-\mathrm{t} 1$ and $-\mathrm{t} 12$ in advanced options). cDNA contigs were also submitted to MG-RAST (Meyer et al., 2008), and ORFs were detected and annotated according to their standard bioinformatics pipeline. Data have been deposited in in MG-RAST under accession numbers 4517418.3, 4517417.3, 4517416.3, 4517415.3, 4517414.3.

\section{Taxonomic Annotation of Contigs}

Contigs were assigned to high-level taxonomic groups (Class level and above) using a Naïve Baysien Classifier (NBC) that compares against a database containing all DNA sequences in NCBI that classified as either Bacteria, Archaea, Fungi, or viral (Rosen and Essinger, 2010). This approach was chosen because NBC has been found to outperform most other composition, similarity, and phylogeny based metagenomic classifiers in terms of sensitivity and precision (Bazinet and Cummings, 2012). Custom perl scripts were used to merge NBC taxonomic identifications of contigs, with COG and Pfam annotations from RPS-BLAST searches together with average coverage (read mapping) from assemblies.

\section{Mapping of Metatranscriptomic Data to M. barkeri Methanogenesis Pathways}

The bioinformatics pipeline for metatranscriptomic genome recruitment followed that described recently (Orsi et al., 2015). In brief, contigs from frozen and thawed metatranscriptomes were searched for homology in the genome of M. barkeri via BLASTx $\left(\mathrm{e}^{-5},>60\right.$ amino acid identity) searches using the translated amino acid sequences of $M$. barkeri genes as a reference. Expressed genes with homology M. barkeri proteins were subjected to metabolic pathway mapping in KEGG (http://www.genome.jp/kegg/pathway.html). Expressed genes with homology to the M. barkeri genome involved in methanogenesis pathways were visualized using Adobe Illustrator (Adobe Systems Inc., San Jose, CA).

\section{Analysis of Gene Overexpression in Frozen vs. Thawed Soil Samples}

Analyses of gene overexpression in frozen vs. thawed samples was performed using the $\mathrm{R}$ statistical package (http://www.r-project.org/), with the MG-RAST matR library (metagenomics.anl.gov). To maintain abundance information, assembled contig sequences from each sample were uploaded to MG RAST with the read mapping abundance added to the fasta headers as specified on the MG RAST website. Differences in 
overexpression between frozen and thawed permafrost samples were determined by a One-Way ANOVA test with a $P$-value cutoff of 0.025 . The relatively low number of rRNA reads that were present in the dataset despite the selective amplification of mRNA using the Ovation RNA-Seq v2 System ${ }^{\circledR}$ were removed prior to comparison. Data were normalized in MG RAST with a $\log$-based transformation $\left[Y_{\mathrm{s}, \mathrm{i}}=\log _{2}\left(X_{\mathrm{s}, \mathrm{i}}+1\right)\right]$, where $X_{\mathrm{s}, \mathrm{i}}$ represents an abundance measure $(i)$ in sample $(s)$. Log transformed counts from each sample were then standardized (data centering) according to the equation $\left[Z_{\mathrm{s}, \mathrm{i}}=\left(Y_{\mathrm{s}, \mathrm{i}}-Y_{\mathrm{s}}\right) /\right.$ $\left.\sigma_{\mathrm{s}}\right)$ ], where $Z_{\mathrm{s}, \mathrm{i}}$ is the standardized abundance of an individual measure $Y_{\mathrm{s}, \mathrm{i}}$ (log transformed from previous equation). From each $\log$ transformed measure of $(i)$ in sample $(s)$, the mean of all transformed values $\left(Y_{\mathrm{s}}\right)$ is subtracted and the difference is divided by the standard deviation $\left(\sigma_{s}\right)$ of all log-transformed values for the given sample. After log transformation and standardization, the values for the functional categories within each sample were scaled from 0 (minimum value of all samples) to 1 (maximum value of all samples), which is a uniform scaling that does not affect the relative differences of values within or between samples. The top 100 processes which differed most substantially in the level of gene expression between frozen and thawed samples and which passed the One-Way ANOVA test were used as input for heatmap presentation, hypothetical proteins and proteins of unknown function were removed from the list of top 100 processes after creating the heatmap.

\section{Results and Discussion}

\section{Composition of Permafrost SOM}

SOM composition, as indicated by bulk metrics (TOC, TN, $\delta^{13} \mathrm{C}, \delta^{15} \mathrm{~N}$ ) and lipid biomarkers (fatty acids [FAs] and alkanes), reflected mainly higher plant sources (Figure 1). \%TOC and \% TN were fairly constant throughout the soil core, with maximum values at $33.5 \mathrm{~cm}$ depth (Figure 1A). Elevated \%TOC at $33.5 \mathrm{~cm}$ suggests that this horizon represents the permafrost table, assuming that cryoturbation under the tussock tundra and dwarf shrub vegetation has caused frost-churning of organic matter into the underlying mineral soil horizons, which then concentrated in the upper permafrost (Ping et al., 1997). Bulk soil $\delta^{13} \mathrm{C}$ signatures ranged from -26 to $-27 \%$, reflecting inputs from $\mathrm{C}_{3}$ plants (Figure 1A). Soil $\delta^{15} \mathrm{~N}$ was most enriched in the deepest horizon (Figure 1A), which could be indicative of several processes including preferential mineralization and plant uptake of isotopically light nitrogen compounds, microbial production of ${ }^{15} \mathrm{~N}$ enriched compounds during decomposition, and contributions from mycorrhizal fungi (Hogberg, 1997; Hobbie and Hobbie, 2008). The permafrost table was most depleted in $\delta^{15} \mathrm{~N}$, suggesting a lower degree of decomposition of plant organic matter than in the deeper soil horizons (Andersson et al., 2012). Concentrations of total alkanes and FAs were generally highest in the deepest soil horizon and lower at shallower depths. Long chain FAs [even $\Sigma\left(\mathrm{C}_{24: 0}-\mathrm{C}_{28: 0}\right)$ ] (Killops and Killops, 2005) and alkanes $\left[\Sigma\left(\mathrm{C}_{22: 0}-\mathrm{C}_{33: 0}\right)\right]$ (Yunker et al., 1995) characteristic of vascular plants were important constituents of the total FA and alkane pools, accounting for $42-51$ and $56-82 \%$, respectively
(Figure 1B). The $\mathrm{CPI}_{\text {alkane }}$ was $>5$, ranging from 5.17 at $49 \mathrm{~cm}$ to 7.75 at $126 \mathrm{~cm}$, indicating that inputs from higher plants were important. The $\mathrm{P}_{\text {wax }}$ and $\mathrm{P}_{\mathrm{aq}}$ indices suggested that contributions from higher plants were high while inputs from aquatic macrophytes were low at all depths except for 49 and $126 \mathrm{~cm}$. In combination, the FAs and $n$-alkanes suggested that higher plants were the main source of SOM and likely deposited under drier conditions. However, aquatic macrophytes and mosses may have been important sources of SOM 2900 and 4100 calendar years before the present (cal. a BP) (Figure 1B) and conditions may have been wetter during those periods.

Lipid biomarkers reflecting bacterial inputs and processes indicated microbial decomposition occurred throughout the core. Contributions from bacterial FAs [iso-, anteiso- odd $\Sigma$ $\left.\left(\mathrm{C}_{13: 0}-\mathrm{C}_{17: 0}\right)\right]$ (Meyers, 2003) were similar across depth horizons but were greatest at $126 \mathrm{~cm}$ (Figure 1B). Microbial decomposition of SOM occurred in all of the soil horizons, as indicated by the presence of Olean-13(18)-ene and Olean-12-ene, which are diagenetic products of higher plants (Yunker et al., 1995), and the ratio of branched $\mathrm{C}_{15}: \mathrm{C}_{14}$ FAs (Lu and Meyers, 2009) (Figure 1B). Since iso- and anteiso- $\mathrm{C}_{15}$ compounds are produced by bacteria from straight chain $\mathrm{C}_{14}$ precursors, an increase in the ratio of branched $\mathrm{C}_{15}$ : straight chain $\mathrm{C}_{14}$ compounds may reflect organic matter decomposition (Lu and Meyers, 2009). Thus, SOM decomposition may be most extensive in the deepest soil horizon where branched $\mathrm{C}_{15}: \mathrm{C}_{14}$, contributions from bacterial FAs, and concentrations of total FAs and alkanes were the highest.

Overall, these results indicate that SOM was largely derived from vascular plants and microbial decomposition occurred throughout the soil column. Microbial breakdown of SOM may have occurred during deposition or after the soils were frozen, but we cannot distinguish between these possibilities based on the lipid biomarker results.

\section{Overview of the Metatranscriptomic Datasets}

An average of 29,022 contigs $(S D=8951)$ with an average length of $616(S D=52)$ were assembled de-novo from each Illumina-sequenced metatranscriptome, with $87 \%(S D=3 \%)$ of original reads mapping to contigs per sample (Supplementary Table S1). Open reading frames (ORFs) on contigs were assigned to COG (Cluster of Orthologous Genes) functional classes and high-level taxonomic groups (Class level and above). Transcribed ORFs with homology to proteins representing 22 out of the 25 defined Clusters of Orthologous Genes (Tatusov et al., 1997) were detected in metatranscriptomes from both frozen and thawed permafrost. Similar to a previous study utilizing the same cDNA amplification and sequence classification procedures (Orsi et al., 2013), the majority of reads could be annotated $(86 \pm 6 \%)$ in each sample, with the majority (79 \pm $7 \%)$ of annotated reads coding for proteins and a minimal representation $(7 \pm 2 \%)$ of ribosomal RNA reads (Supplementary Table S1).

\section{Overexpressed Genes under Frozen Conditions}

Amino acid transport and metabolism, energy production, and DNA repair, replication and recombination were amongst the 
most relatively abundant $\mathrm{COG}$ categories expressed in the frozen permafrost (Figure 2A). The expression of genes corresponding to most major COG families in frozen permafrost suggests the in situ activity of microbes, even at subfreezing temperatures. The variability in relative abundances of COGs was markedly less in metatranscriptomes from frozen samples, compared to the metatranscriptomes from thawed permafrost (Figure 2A) Phylogenetic binning indicates that Proteobacteria $(\gamma, \beta, \alpha$, and $\delta)$, Firmicutes, Acidobacteria, and Actinobacteria, as well as Euryarchaeota and ascomycetous Fungi were the most transcriptionally active microbial groups under frozen conditions in the permafrost table (Figure 2B). These taxa are frequently reported from Arctic soils (Jansson and Tas, 2014 and references therein).

Several transcripts encoding proteins involved in biofilm formation, virulence, and horizontal gene transfer had relatively higher expression levels under frozen conditions (Figure 3). Notably, expression of genes coding for pilus assembly proteins (COGs 2064, 1706, 4964, 3166) may indicate biofilm formation, which is a common feature among bacteria living under stressful conditions and causes a close interaction between cells that can promote virulence, bacterial signaling, and/or horizontal gene transfer (Varga et al., 2008). Biofilm formation in the frozen soils may be related to the small area available for growth in the permafrost microhabitat where the current consensus is that microbes inhabit very thin liquid brine veins surrounding frozen soil particles (Gilichinsky et al., 2003, 2005; Shcherbakova et al., 2005; Onstott et al., 2009; Pecheritsyna et al., 2012). Active defense against viral infection is indicated by the activity of a Type II restriction-modification system (i.e., site-specific DNA methylase COG0338; Figure 3), which can protect bacteria and archaea against invading foreign DNA (Pingoud et al., 2005). However, virulence-associated genes were also overexpressed in thawed soils, suggesting active viral defenses during both frozen and thawed conditions. Enzymes involved in DNA repair were also overexpressed in frozen soils (Figure 3). Uracil-DNA glycolases are involved in base excision repair, a process that removes damaged bases that could otherwise lead to mutations (Kim and Wilson, 2012). Recently, an ionization radiation (IR) experiment with a frozen culture of Psychrobacter arcticus suggested that, in the presence of long-term natural background IR, permafrost bacteria can repair double stranded DNA breaks in the absence of net growth (Dieser et al., 2013). Our results support this observation, and suggest that in situ, uracil-DNA glycolases play an important role in DNA repair incurred from long-term exposure to natural background IR sources in the permafrost environment. Compared to thawed soils, a gene sequence encoding a $\operatorname{RecA}$ mediated autopeptidase was relatively more abundant in the permafrost sequence datasets further suggesting that bacterial "Save Our Ship" (SOS)-response occurs in the frozen soils (Figure 3). SOS-response is a global response to DNA damage in which the cell cycle is arrested and DNA repair is induced (Michel, 2005). Such DNA repair and stress response mechanisms likely allow microbes to survive over geological timescales in permafrost until favorable conditions for growth are experienced, such as thawed conditions resulting from increasing atmospheric temperatures.

\section{Overall Transcriptional Activity Stimulated Under Thawed Conditions}

Compared to the frozen samples, all three thawed permafrost intervals exhibit relatively increased representation of transcripts involved in translation, ribosomal structure, and biogenesis, indicating a general increase in microbial activity and growth (Figure 2A). In thawed samples from the permafrost table, metatranscriptomes had an increased proportion of transcripts involved in coenzyme transport and metabolism compared to metatranscriptomes from frozen permafrost table samples (Figure 2A). The majority of transcripts falling into this functional category in permafrost table metatranscriptomes were assigned to Euryarchaeota (Figure 2B).

Overall, there was increased representation of Firmicutes, Bacteroidetes, Euryarchaeota, and ascomycetous Fungi in metatranscriptomes from thawed samples relative to Proteobacteria, Acidobacteria, and Actinobacteria (Figure 2B). The thawed permafrost table at $33.5 \mathrm{~cm}$ showed the largest relative increase in fungal-derived transcripts, compared to the frozen sample from this horizon. The thawed horizon at $49 \mathrm{~cm}$, revealed the largest relative increase in transcripts assigned to Firmicutes compared to frozen permafrost at this depth, and a similar proportion of transcripts were assigned Firmicutes in thawed samples from $68 \mathrm{~cm}$ (Figure 2B). This may be due to the germination of spores in permafrost soils after thawed conditions (Steven et al., 2008; Niederberger et al., 2009). Transcripts assigned to Chloroflexi and Crenarchaeota involved in translation, ribosomal structure and biogenesis at $49 \mathrm{~cm}$ increased in relative abundance in metatranscriptomes from thawed samples (Figure 2B). Similar proportions of transcripts were assigned to Chloroflexi and Crenarchaeota in metatranscriptomes from thawed permafrost at $68 \mathrm{~cm}$. Transcriptional activity of these phyla mainly increased in the deeper thawed soils, suggesting that they may be specialized in the initial decomposition of more complex, ancient SOM.

Relative to the frozen samples, thawed metatranscriptomes exhibit an upregulation of genes coding for enzymes involved in extracellular protein degradation (notably Aminopeptidase C) (Figure 3). This suggests microbial utilization of labile proteins as a source of $\mathrm{N}$ and $\mathrm{C}$ during thawed conditions. Thawed metatranscriptomes also had a relative increase in transcripts encoding proteins involved in uptake, transport, and degradation of carbohydrates (e.g., ABC type sugar transporter, a predicted sugar isomerase, 6-phosphogluconate dehydrogenase, fructose 1,7 biphosphatase, and a pyruvate formate lyaseactivating enzyme) (Figure 3). Upon thawed conditions, some of the microbial metabolism appears to be anaerobic, as evidenced by the relative increased expression of the pyruvateformate lyase-activating enzyme (Figure 3), which catalyzes the anaerobic conversion of pyruvate and coenzyme A into acetyl CoA and formate (Jiang et al., 2001).

\section{Transcriptional Evidence for Enzymatic Decomposition of Complex Soil Biopolymers under Thawed Conditions}

Genes encoding for all major classes of hydrolases involved in the cleavage of complex biopolymers into $\mathrm{C} 1$ and $\mathrm{C} 2$ substrates 


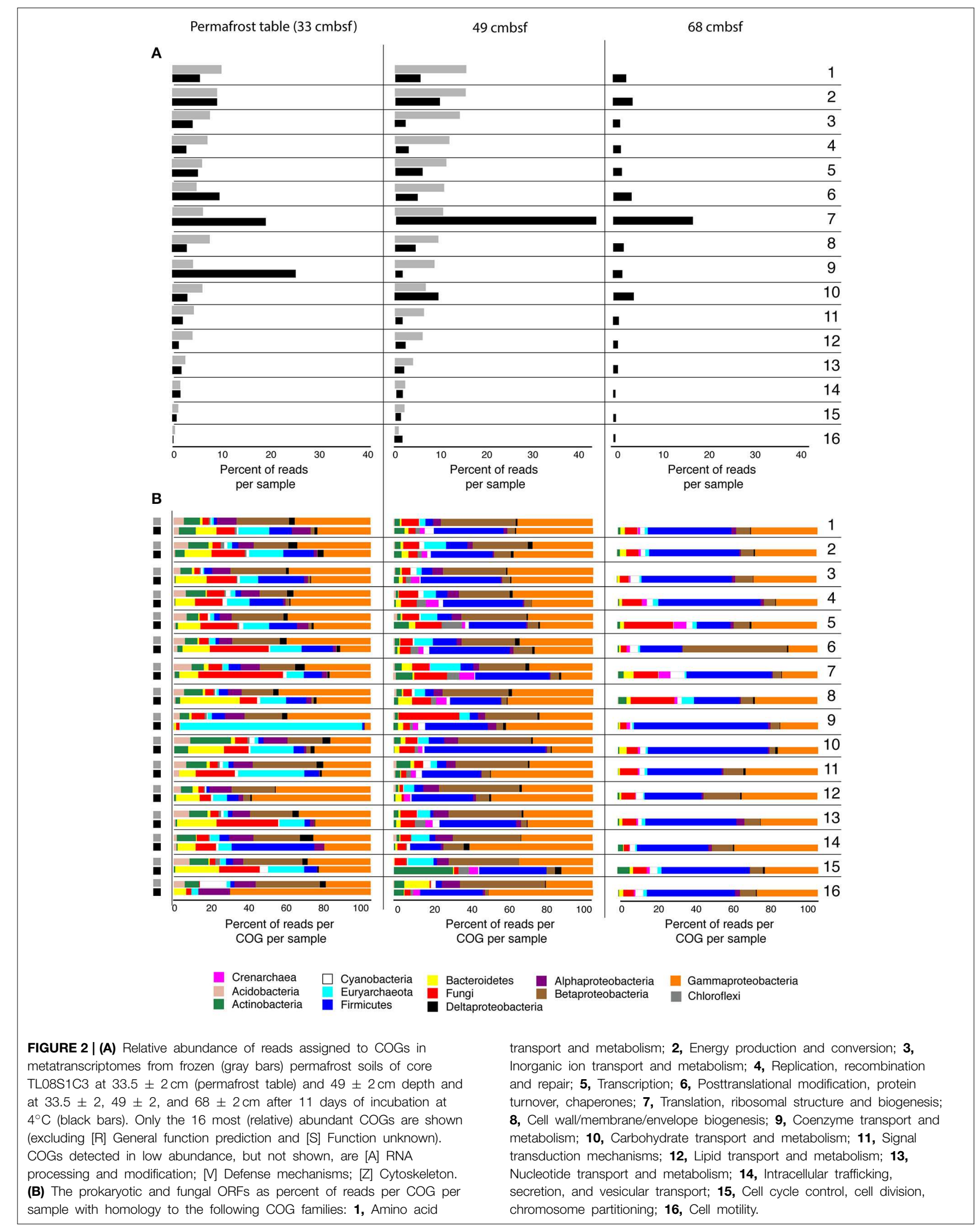




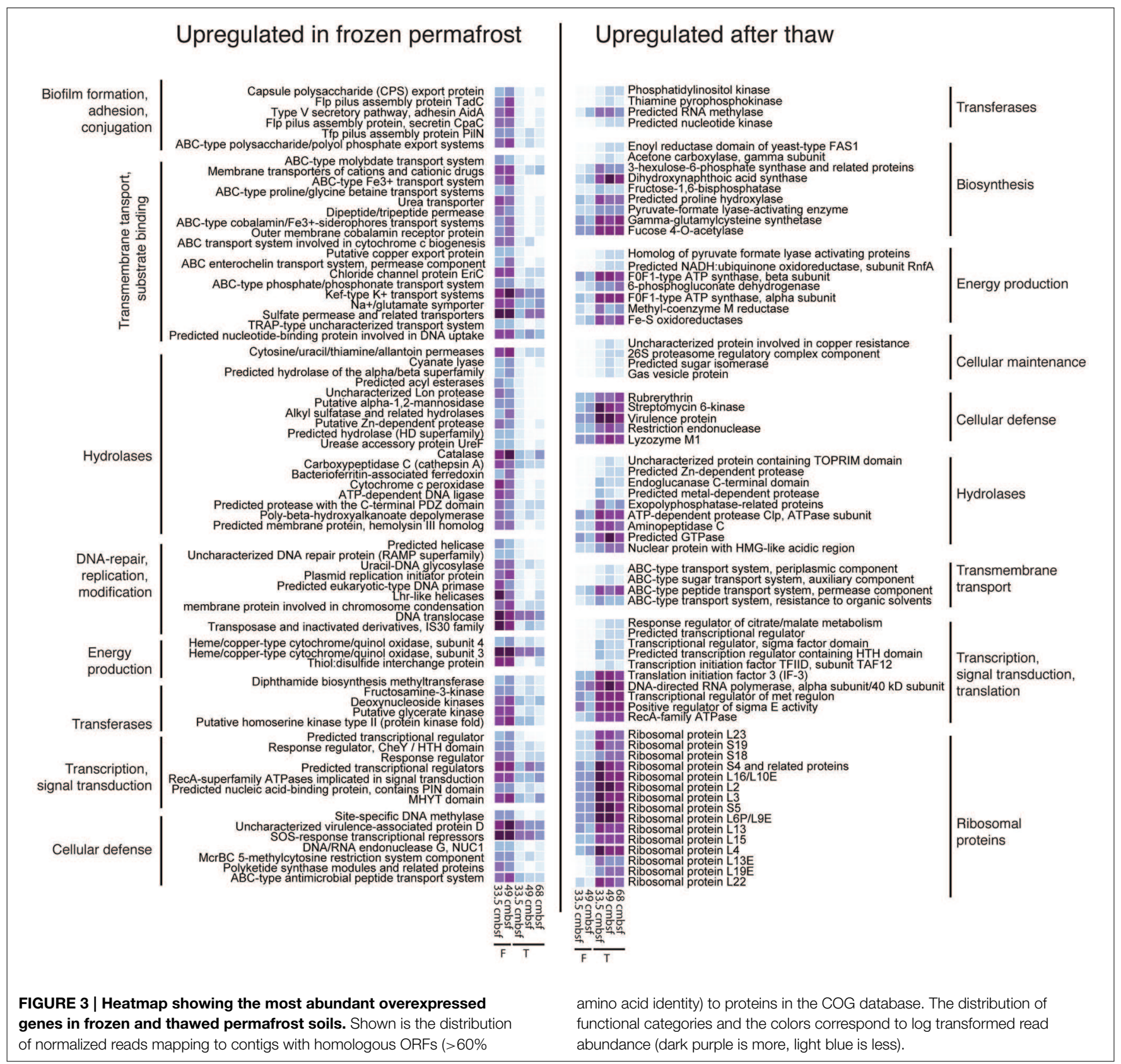

were expressed in both frozen and thawed soils (Figure 4A). The relative distribution of hydrolase-encoding transcripts at the shallowest interval (permafrost table), revealed a relative increase in peptidase encoding transcripts in thawed samples (Figure 4A). This difference was not observed for the deeper permafrost sample $(49 \mathrm{~cm})$, and may indicate increased bioavailability of peptides at $33.5 \mathrm{~cm}$ after thaw. Most of this relative increase in peptidase encoding transcripts at $33.5 \mathrm{~cm}$ could be attributed to the activity of euryarchaea and bacteroidetes (Figure 4A). This confirms our earlier findings based on detectable activities of leucine aminopeptidase at this depth interval, indicating that the permafrost table contains relatively labile polypeptides or proteins as source of C and N (Coolen et al., 2011).
The diversity of taxa expressing hydrolase encoding transcripts in the deeper permafrost decreased markedly relative to $33.5 \mathrm{~cm}$, with Firmicutes-derived hydrolase encoding transcripts increasing in relative representation after thaw (Figure 4A). A similar response was observed for crenarchaeal transcripts encoding glycosylases and peptidases, which were only observed in the two deepest thawed permafrost intervals (Figure 4A). Despite the overall increase in activity of Chloroflexi in the thawed soil interval at $49 \mathrm{~cm}$ (Figure 2B), transcripts homologous to Chloroflexi-derived hydrolases acting on complex soil biopolymers were not observed early after thaw (Figure 4A). Their role in the cycling of organic matter in permafrost soils requires further investigation. 

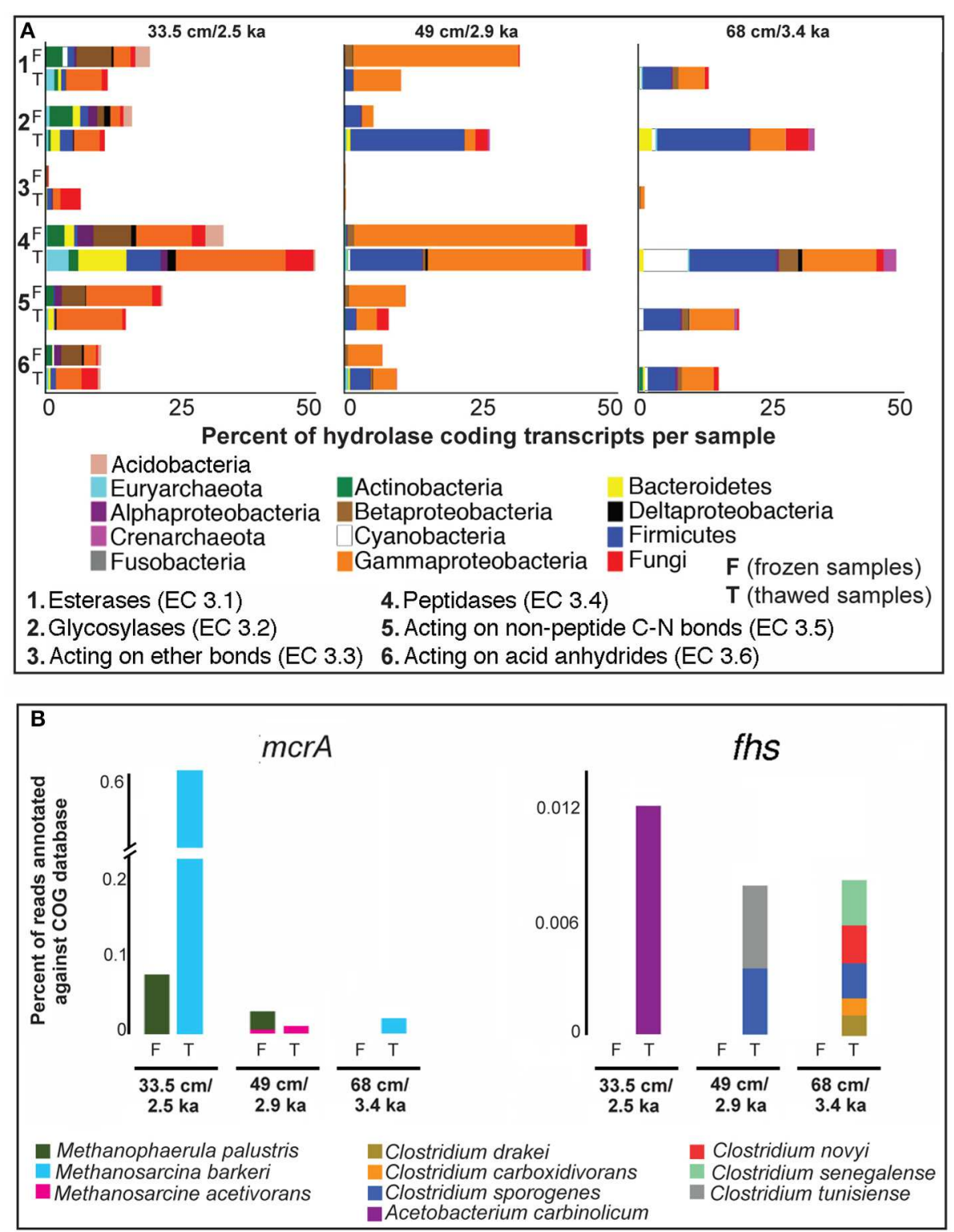

FIGURE 4 | Expressed homologs, (relative abundance) encoding (A) hydrolases potentially involved in the initial breakdown of of complex permafrost soil biopolymers, and (B) formyltetrahydrofolate synthetase (fhs) and methyl-coenzyme reductase A (mcrA) before and after 11 days of thaw. Note the predominance of concomitant mcrA (methanogenesis) and fhs (acetogenesis) expression in thawed samples relative to frozen samples.
Upon thawed conditions in the permafrost table, relative expression of fungal, $\gamma$-Proteobacterial, and Firmicutes genes encoding hydrolases acting on recalcitrant ether bonds increased (Figure 4A). Ether bonds occur in the tetraether membranes of yet unidentified soil bacteria (i.e., branched Glycerol Dialkyls Glycerol Tetraethers [branched GDGTs]), commonly found in peat soils (Weijers et al., 2007), as well as in isoprenoid GDGTs of (methanogenic) archaea (Schouten et al., 2000). The increased transcription of genes encoding hydrolases acting on ether bonds in the permafrost table upon thaw suggests that some permafrost microbiota at $33.5 \mathrm{~cm}$ decompose dead bacterial and/or archaeal biomass. Collectively these data suggest that thawed conditions stimulate growth and turnover of archaeal and bacterial biomass in soil permafrost.

Relative expression of genes with homology to cyanobacterial peptidases and hydrolases acting on non-peptide $\mathrm{C}-\mathrm{N}$ bonds and anhydrides was highest in the deepest analyzed thawed permafrost interval (Figure 4A). The activity in permafrost soils in the absence of light seems counter-intuitive. However, oligopeptides and or amino acids may serve as nitrogen sources for cyanobacteria in permafrost soils, as they have been reported to assimilate organic compounds for biosynthesis during the dark 
phase of their life cycle (Vernotte et al., 1992). Lay et al. (2013) reported the presence of cyanobacterial genes involved in the reduction of nitrate to ammonia in high-Arctic saline subzero spring sediments, and they suggested that this strategy might be advantageous for maintaining activity during the long-term darkness of the Arctic winter. Our results suggest that cyanobacteria may be dormant in the deeper permafrost soils for substantial periods of time and can regain activity under dark conditions within days after thaw.

\section{Active Metabolic Pathways for Methanogenesis and Acetogenesis Stimulated under Thawed Conditions}

Metatranscriptomes from thawed permafrost exhibited a marked relative increase in transcripts involved in coenzyme transport and metabolism (Figure 2A). In the permafrost table, metatranscriptomes in this category were mainly assigned to Euryarchaeota (Figure 2B). The most predominant transcript in this category was methyl coenzyme $\mathrm{M}$ reductase subunit A (mcrA), which catalyzes the last step in methanogenesis and is present in all methanogens (Ferry, 1999). More specifically, the morA transcripts in the thawed permafrost table were assigned to the versatile methanogen Methanosarcina barkeri, capable of using a variety of $\mathrm{C}_{1}$ and $\mathrm{C}_{2}$ compounds including acetate (Weimer and
Zeikus, 1979; Jetten et al., 1992). The identification of M. barkeri as the main producer of $m c r A$ transcripts is plausible since acetate concentrations in permafrost samples can be 50 times higher (Strauss et al., 2012) than the minimum acetate requirement ( $\sim 200 \mu \mathrm{M})$ of Methanosarcina spp. (Jetten et al., 1992). Expression of methano phenazine-reducing hydrogenase $(m p h)$, which is indicative of heterotrophic methanogenic metabolism, was also detected after thaw, suggesting $\mathrm{C} 1$ and $\mathrm{C} 2$ substrates as sources of biogenic methane. Further metabolic mapping of expressed genes to the $M$. barkeri genome indicated an increase in active biochemical pathways utilizing acetate, trimethylamine, and methanol as methanogenic substrates (Figure 5). Expression of genes coding for formylmethanofuran-tetrahydromethanopterin $\mathrm{N}$-formyltransferase ( $f t r$ ) (a protein necessary completing the pathway from methanogenesis from $\mathrm{CO}_{2}$ ), was not detected, suggesting a predominance of heterotrophic methanogenesis after thaw. A marked increase in acetoclastic methanogensis was recently also reported from thawed permafrost soils in northern Sweden (McCalley et al., 2014). In addition, recent biogeochemical examination of peat and dissolved organic matter (DOM) at northern Sweden permafrost sites that had been exposed to thaw for up to 40 years revealed a shift in $\mathrm{CH}_{4}$ production pathway from $\mathrm{CO}_{2}$-reduction to acetate cleavage, which was associated with (i) increased humification rates, (ii) DOM shifted

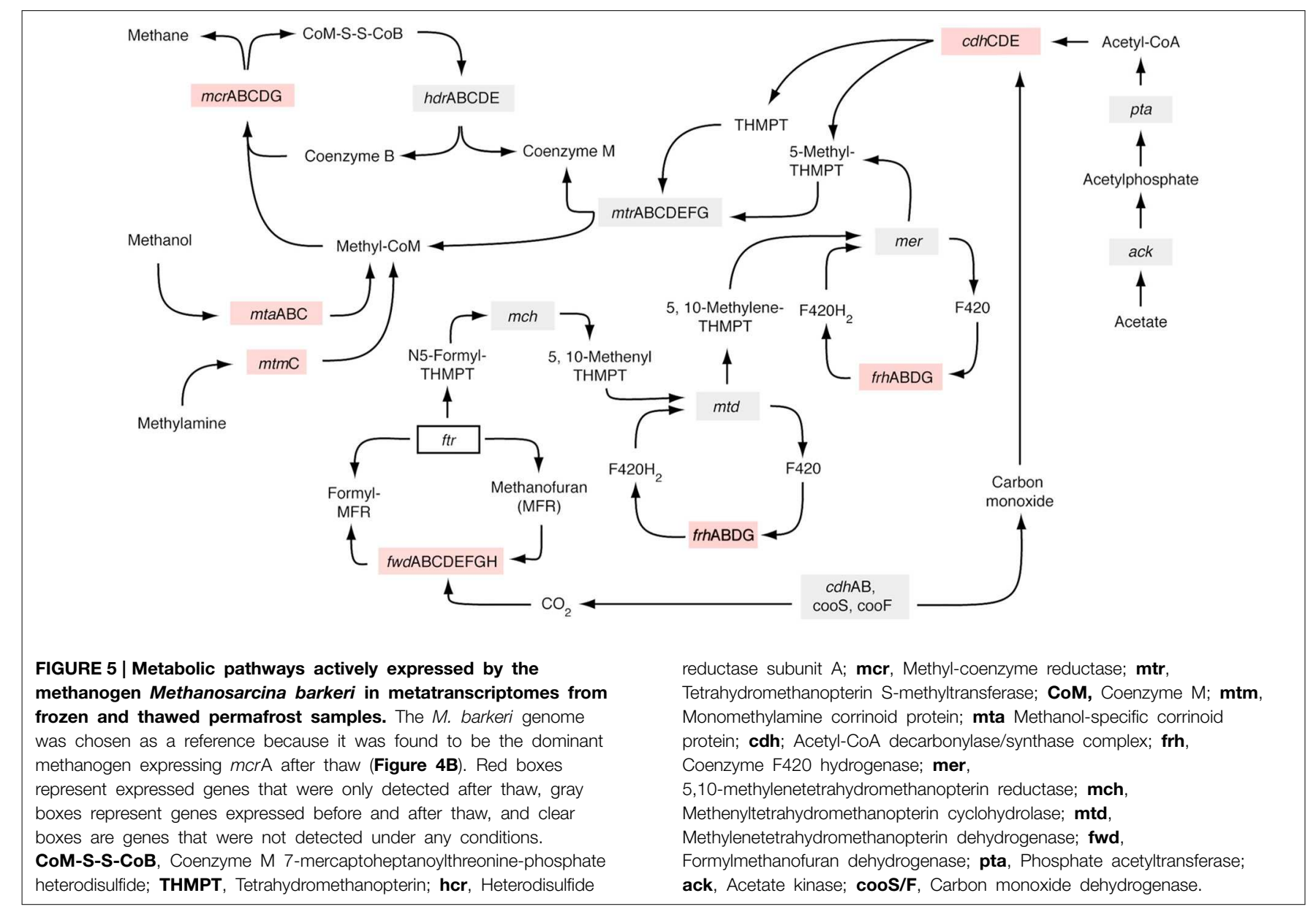


toward lower molecular weight compounds with lower aromaticity, (iii) lower organic oxygen content, and (iv) more abundant microbially produced compounds (Hodgkins et al., 2014).

In all thawed permafrost samples, an increase in $m c r$ A expression was accompanied by an increase in expression of formyltetrahydrofolate synthetase (fhs) genes (not detected in frozen permafrost), which can serve as a proxy for acetogenesis (Lever, 2013) (Figure 4B). Transcripts encoding fhs in the upper permafrost were assigned predominantly to Acetobacterium carbinolicum, whereas various Clostridium species are likely involved in acetate production in deeper permafrost (Figure 4B). The genetic expression of the acetate-utilizing methanogenesis pathway (Figure 5) after thaw suggests that some of this acetate is then utilized as a substrate by methanogens, predominantly M. barkeri (Figure 4B). Acetogenic fermentation, which is also likely under anaerobic conditions in thawed permafrost, could be another source of acetate for acetoclastic methanogens. Bacterial genes encoding the two enzymes diagnostic for fermentative conversion of acetyl-CoA to acetate (acetate kinase, EC:2.7.2.1 and phosphotransacetylase EC:2.3.1.8) were not detected in thawed permafrost, suggesting that pyruvate fermentation to acetate may not be a dominant source of acetate, relative to homoacetogenesis. However, to substantiate the claim of homoacetogenesis dominating over fermentation as a source of acetate in thawing permafrost soils, it is necessary to perform radiotracer incubations or to analyze the stable isotopic composition of acetate in these soils (Rivkina et al., 2000; Bakermans and Skidmore, 2011).

\section{Concluding Remarks}

Our pilot study shows that the analysis of metatranscriptomes is a sensitive approach capable of identifying a wide spectrum of important metabolic processes in frozen and thawed permafrost. In general, the transcriptional profile under frozen conditions suggests a dominance of stress responses, survival strategies, and maintenance processes whereas upon thaw a rapid enzymatic response to decomposing SOM was observed. Furthermore, our

\section{References}

Andersson, R. A., Meyers, P., Hornibrook, E., Kuhry, P., and Morth, C. M. (2012). Elemental and isotopic carbon and nitrogen records of organic matter accumulation in a Holocene permafrost peat sequence in the East European Russian Arctic. J. Q. Sci. 27, 545-552. doi: 10.1002/ jqs. 2541

Anisimov, O. A., Nelson, F. E., and Pavlov, A. V. (1999). Predicitive scenarios of permafrost development under conditions of global change in the XXI century. Earth Cryol. 3, 15-25.

Ayala-Del-Rio, H. L., Chain, P. S., Grzymski, J. J., Ponder, M. A., Ivanova, N., Bergholz, P. W., et al. (2010). The genome sequence of Psychrobacter arcticus 273-4, a psychroactive Siberian permafrost bacterium, reveals mechanisms for adaptation to low-temperature growth. Appl. Environ. Microbiol. 76, 2304-2312. doi: 10.1128/AEM.02101-09

Bakermans, C., and Skidmore, M. L. (2011). Microbial Metabolism in Ice and Brine at $-5^{\circ}$ C. Environ. Microbiol. 13, 2269-2278. doi: 10.1111/j.14622920.2011.02485.x analysis indicates that acetoclastic methanogenesis may be a dominant form of methanogenesis in thawing permafrost soils fueled, in part, by acetate production from acetogenic bacteria. Due to large heterogeneity in permafrost SOM and microbial composition, future metatranscriptome studies should be performed from a wider variety of permafrost soil types and locations, and in comparison with the active layer. Future studies comparing metatranscriptomes from thawing permafrost should also contain biological replicates to provide robust statistical power for hypothesis testing. Furthermore, paired geochemical analysis of isotopically labeled substrates and metabolites during thaw incubation experiments as well as the analysis of the stable isotopic composition and concentration of dissolved methane should be performed to validate mRNA-based inferences of metabolic pathways. Measurements of soil $\mathrm{pH}$ would further be useful to contextualize microbial responses to permafrost thaw at the transcriptional level. Metatranscriptomics is shown here to be a useful approach for inferring the activity of permafrost microbes, that has potential to improve our understanding of permafrost SOM bioavailability and biogeochemical mechanisms contributing to greenhouse gas emissions as a result of warming induced permafrost thaw.

\section{Acknowledgments}

We thank Dr. Amanda Spivak (WHOI) for the analysis of the permafrost organic matter composition and the interpretation of the lipid data as well as Dr. Cornelia Wuchter (WHOI) for helpful general discussions. This work was fostered by grants from WHOI's Arctic Research Initiative to MJLC and AS, as well as a Center for Dark Energy Biosphere Investigations (CDEBI) grant OCE-0939564 to WDO. This is C-DEBI Contribution 258.

\section{Supplementary Material}

The Supplementary Material for this article can be found online at: http://www.frontiersin.org/journal/10.3389/fmicb. 2015.00197/abstract
Bakermans, C., Skidmore, M. L., Douglas, S., and McKay, C. P. (2014) Molecular characterization of bacteria from permafrost of the Taylor Valley, Antarctica. Fems Microbiol. Ecol. 89, 331-346. doi: 10.1111/1574-6941. 12310

Bazinet, A. L., and Cummings, M. P. (2012). A comparative evaluation of sequence classification programs. BMC Bioinformatics 13:92. doi: 10.1186/14712105-13-92

Bellemain, E., Davey, M. L., Kauserud, H., Epp, L. S., Boessenkool, S., Coissac, E., et al. (2013). Fungal palaeodiversity revealed using high-throughput metabarcoding of ancient DNA from arctic permafrost. Environ. Microbiol. 15, 1176-1189. doi: 10.1111/1462-2920.12020

Coolen, M. J. L., Van De Giessen, J., Zhu, E. Y., and Wuchter, C. (2011). Bioavailability of soil organic matter and microbial community dynamics upon permafrost thaw. Environ. Microbiol. 13, 2299-2314. doi: 10.1111/j.14622920.2011.02489.x

Cranwell, P. A., Eglinton, G., and Robinson, N. (1987). Lipids of aquatic organisms as potential contributors to lacustrine sediments.2. Organ. Geochem. 11, 513-527. doi: 10.1016/0146-6380(87)90007-6 
Dieser, M., Battista, J. R., and Christner, B. C. (2013). DNA double-strand break repair at $-15^{\circ} \mathrm{C}$. Appl. Environ. Microbiol. 79, 7662-7668. doi: 10.1128/AEM.02845-13

Dutta, K., Schuur, E. A. G., Neff, J. C., and Zimov, S. A. (2006). Potential carbon release from permafrost soils of Northeastern Siberia. Glob. Change Biol. 12, 2336-2351. doi: 10.1111/j.1365-2486.2006.01259.x

Ferry, J. G. (1999). Enzymology of one-carbon metabolism in methanogenic pathways. Fems Microbiol. Rev. 23, 13-38. doi: 10.1111/j.1574-6976.1999.tb00390.x

Ficken, K. J., Li, B., Swain, D. L., and Eglinton, G. (2000). An n-alkane proxy for the sedimentary input of submerged/floating freshwater aquatic macrophytes. Organ. Geochem. 31, 745-749. doi: 10.1016/S0146-6380(00)00081-4

Frank-Fahle, B. A., Yergeau, E., Greer, C. W., Lantuit, H., and Wagner, D. (2014). Microbial functional potential and community composition in permafrostaffected soils of the NW canadian arctic. PLoS ONE 9:e84761. doi: 10.1371/journal.pone.0084761

Ganzert, L., Bajerski, F., and Wagner, D. (2014). Bacterial community composition and diversity of five different permafrost-affected soils of Northeast Greenland. Fems Microbiol. Ecol. 89, 426-441. doi: 10.1111/1574-6941.12352

Gilichinsky, D., Rivkina, E., Bakermans, C., Shcherbakova, V., Petrovskaya, L., Ozerskaya, S., et al. (2005). Biodiversity of cryopegs in permafrost. FEMS Microbiol. Ecol. 53, 117-128. doi: 10.1016/j.femsec.2005.02.003

Gilichinsky, D., Rivkina, E., Shcherbakova, V., Laurinavichuis, K., and Tiedje, J. (2003). Supercooled water brines within permafrost - An unknown ecological niche for microorganisms: a model for astrobiology. Astrobiology 3, 331-341. doi: $10.1089 / 153110703769016424$

Hobbie, E. A., and Hobbie, J. E. (2008). Natural abundance of (15)N in nitrogenlimited forests and tundra can estimate nitrogen cycling through mycorrhizal fungi: a review. Ecosystems 11, 815-830. doi: 10.1007/s10021-008-9159-7

Hobbie, S. E., and Gough, L. (2004). Litter decomposition in moist acidic and non-acidic tundra with different glacial histories. Oecologia 140, 113-124. doi: 10.1007/s00442-004-1556-9

Hodgkins, S. B., Tfaily, M. M., McCalley, C. K., Logan, T. A., Crill, P. M., Saleska, S. R., et al. (2014). Changes in peat chemistry associated with permafrost thaw increase greenhouse gas production. Proc. Natl. Acad. Sci. U.S.A. 111, 5819-5824. doi: 10.1073/pnas.1314641111

Hogberg, P. (1997). Tansley review No $95.15 \mathrm{~N}$ natural abundance in soil-plant systems. New Phytol. 137, 179-203. doi: 10.1046/j.1469-8137.1997.00808.x

Huang, Q. Y., Briggs, B. R., Dong, H. L., Jiang, H. C., Wu, G., Edwardson, C., et al. (2014). Taxonomic and functional diversity provides insight into microbial pathways and stress responses in the saline Qinghai Lake, China. PLoS ONE 9:e116444. doi: 10.1371/journal.pone.0111681

Jansson, J. K., and Tas, N. (2014). The microbial ecology of permafrost. Nat. Rev. Microbiol. 12, 414-425. doi: 10.1038/nrmicro3262

Jetten, M. S. M., Stams, A. J. M., and Zehnder, A. J. B. (1992). Methanogenesis from acetate - a comparison of the acetate metabolism in Methanothrix soehngenii and Methanosarcina spp. Fems Microbiol. Lett. 88, 181-197. doi: 10.1111/j.1574-6968.1992.tb04987.x

Jiang, G. R. J., Nikolova, S., and Clark, D. P. (2001). Regulation of the ldhA gene, encoding the fermentative lactate dehydrogenase of Escherichia coli. Microbiology 147, 2437-2446.

Jorgenson, M. T., Racine, C. H., Walters, J. C., and Osterkamp, T. E. (2001). Permafrost degradation and ecological changes associated with a warming climate in central Alaska. Clim. Change 48, 551-579. doi: 10.1023/A:1005667424292

Kane, D. L., Hinzman, L. D., and Zarling, J. P. (1991). Thermal response of the active layer to climatic warming in a permafrost environment. Cold Reg. Sci. Technol. 19, 111-122. doi: 10.1016/0165-232X(91)90002-X

Killops, S., and Killops, V. (2005). Introduction to Organic Geochemistry. Oxford, UK: Blackwell Publishing Ltd.

Kim, Y. J., and Wilson, D. M. III. (2012). Overview of base excision repair biochemistry. Curr. Mol. Pharmacol. 5, 3-13. doi: 10.2174/1874467211205010003

Lay, C. Y., Mykytczuk, N. C. S., Yergeau, E., Lamarche-Gagnon, G., Greer, C. W., and Whyte, L. G. (2013). Defining the functional potential and active community members of a sediment microbial community in a high-Arctic hypersaline subzero spring. Appl. Environ. Microbiol. 79, 3637-3648. doi: 10.1128/AEM.00153-13

Lever, M. A. (2013). Functional gene surveys from ocean drilling expeditions - a review and perspective. FEMS Microbiol. Ecol. 84, 1-23. doi: $10.1111 / 1574-6941.12051$
Li, W. Z. (2009). Analysis and comparison of very large metagenomes with fast clustering and functional annotation. BMC Bioinformatics 10:359. doi: 10.1186/1471-2105-10-359

Liebner, S., Harder, J., and Wagner, D. (2008). Bacterial diversity and community structure in polygonal tundra soils from Samoylov Island, Lena Delta, Siberia. Int. Microbiol. 11, 195-202. doi: 10.2436/20.1501.01.60

Lipson, D. A., Haggerty, J. M., Srinivas, A., Raab, T. K., Sathe, S., and Dinsdale, E. A. (2013). Metagenomic insights into anaerobic metabolism along an Arctic peat soil profile. PLoS ONE 8:e64659. doi: 10.1371/journal.pone.0064659

Lu, Y. H., and Meyers, P. A. (2009). Sediment lipid biomarkers as recorders of the contamination and cultural eutrophication of Lake Erie, 1909-2003. Organ. Geochem. 40, 912-921. doi: 10.1016/j.orggeochem.2009.04.012

Mackelprang, R., Waldrop, M. P., Deangelis, K. M., David, M. M., Chavarria, K. L., Blazewicz, S. J., et al. (2011). Metagenomic analysis of a permafrost microbial community reveals a rapid response to thaw. Nature 480, 368-U120. doi: 10.1038 /nature 10576

McCalley, C. K., Woodcroft, B. J., Hodgkins, S. B., Wehr, R. A., Kim, E.-H., Mondav, R., et al. (2014). Methane dynamics regulated by microbial community response to permafrost thaw. Nature 514, 478-481. doi: 10.1038/nature13798

Meyer, F., Paarmann, D., D'souza, M., Olson, R., Glass, E. M., Kubal, M., et al. (2008). The metagenomics RAST server - a public resource for the automatic phylogenetic and functional analysis of metagenomes. BMC Bioinformatics 9:386. doi: 10.1186/1471-2105-9-386

Meyers, P. A. (2003). Applications of organic geochemistry to paleolimnological reconstructions: a summary of examples from the Laurentian Great Lakes. Organ. Geochem. 34, 261-289. doi: 10.1016/S0146-6380(02)00168-7

Michel, B. (2005). After 30 years of study, the bacterial SOS response still surprises us. PLoS Biol. 3, 1174-1176. doi: 10.1371/journal.pbio.0030255

Niederberger, T. D., Steven, B., Charvet, S., Barbier, B., and Whyte, L. G. (2009). Virgibacillus arcticus sp nov., a moderately halophilic, endospore-forming bacterium from permafrost in the Canadian high Arctic. Int. J. Syst. Evol. Microbiol. 59, 2219-2225. doi: 10.1099/ijs.0.002931-0

Onstott, T. C., McGown, D. J., Bakermans, C., Ruskeeniemi, T., Ahonen, L., Telling, J., et al. (2009). Microbial communities in subpermafrost saline fracture water at the Lupin Au Mine, Nunavut, Canada. Microb. Ecol. 58, 786-807. doi: 10.1007/s00248-009-9553-5

Orsi, W. D., Edgcomb, V. P., Christman, G. D., and Biddle, J. F. (2013). Gene expression in the deep biosphere. Nature 499, 205-208. doi: 10.1038 /nature 12230

Orsi, W. D., Smith, J. M., Wilcox, H. M., Swalwell, J. E., Carini, P., Worden, A. Z., et al. (2015). Ecophysiology of uncultivated marine euryarchaea is linked to particulate organic matter. ISME J. 1-17. doi: 10.1038/ismej.2014.260

Osburn, M. R., Sessions, A. L., Pepe-Ranney, C., and Spear, J. R. (2011). Hydrogen-isotopic variability in fatty acids from Yellowstone National Park hot spring microbial communities. Geochim. Cosmochim. Acta 75, 4830-4845. doi: 10.1016/j.gca.2011.05.038

Osterkamp, T. E. (2007). Characteristics of the recent warming of permafrost in Alaska. J. Geophys. Res. Earth Surf. 112:F02S02. doi: 10.1029/2006JF 000578

Pautler, B. G., Simpson, A. J., McNally, D. J., Lamoureux, S. F., and Simpson, M. J. (2010). Arctic permafrost active layer detachments stimulate microbialactivity and degradation of soil organic matter. Environ. Sci. Technol. 44, 4076-4082. doi: $10.1021 /$ es903685j

Pecheritsyna, S. A., Rivkina, E. M., Akimov, V. N., and Shcherbakova, V. A. (2012). Desulfovibrio arcticus sp nov., a psychrotolerant sulfate-reducing bacterium from a cryopeg. Int. J. Syst. Evol. Microbiol. 62, 33-37. doi: 10.1099/ijs.0. 021451-0

Penton, C. R., St Louis, D., Cole, J. R., Luo, Y., Wu, L., Schuur, E., et al. (2013). Fungal diversity in Permafrost and Tallgrass Prairie soils under experimental warming conditions. Appl. Environ. Microbiol. 79, 7063-7072. doi: 10.1128/AEM.01702-13

Ping, C. L., Michaelson, G. J., and Kimble, J. M. (1997). Carbon storage along a latitudinal transect in Alaska. Nutr. Cycl. Agroecosys. 49, 235-242. doi: 10.1023/A:1009731808445

Pingoud, A., Fuxreiter, M., Pingoud, V., and Wende, W. (2005). Type II restriction endonucleases: structure and mechanism. Cell. Mol. Life Sci. 62, 685-707. doi: $10.1007 /$ s00018-004-4513-1 
Rivkina, E. M., Friedmann, E. I., McKay, C. P., and Gilichinsky, D. A. (2000). Metabolic activity of permafrost bacteria below the freezing point. Appl. Environ. Microbiol. 66, 3230-3233. doi: 10.1128/AEM.66.8.32303233.2000

Rosen, G. L., and Essinger, S. D. (2010). Comparison of statistical methods to classify environmental genomic fragments. IEEE Trans. Nanobiosci. 9, 310-316. doi: 10.1109/TNB.2010.2081375

Schouten, S., Hopmans, E. C., Pancost, R. D., and Sinninghe Damsté, J. S. (2000). Widespread occurrence of structurally diverse tetraether membrane lipids: evidence for the ubiquitous presence of low-temperature relatives of hyperthermophiles. Proc. Natl. Acad. Sci. U.S.A. 97, 14421-14426. doi: 10.1073/pnas.97.26.14421

Schuur, E. A.G., Bockheim, J., Canadell, J. G., Euskirchen, E., Field, C. B., Zimov, S. A. et al. (2008). Vulnerability of permafrost carbon to climate change: implications for the global carbon cycle. Bioscience 58, 701-714. doi: 10.1641/B580807

Sessions, A. L. (2006). Seasonal changes in D/H fractionation accompanying lipid biosynthesis in Spartina alternflora. Geochim. Cosmochim. Acta 70, 2153-2162. doi: 10.1016/j.gca.2006.02.003

Shcherbakova, V. A., Chuvilskaya, N. A., Rivkina, E. M., Pecheritsyna, S. A., Laurinavichius, K. S., Suzina, N. E., et al. (2005). Novel psychrophilic anaerobic spore-forming bacterium from the overcooled water brine in permafrost: description Clostridium algoriphilum sp nov. Extremophiles 9, 239-246. doi: 10.1007/s00792-005-0438-3

Steven, B., Pollard, W. H., Greer, C. W., and Whyte, L. G. (2008). Microbial diversity and activity through a permafrost/ground ice core profile from the Canadian high Arctic. Environ. Microbiol. 10, 3388-3403. doi: 10.1111/j.14622920.2008.01746.x

Strauss, J., Schirrmeister, L., Wetterich, S., and, Mangelsdorf, K. (2012). “Old organic matter in Siberian permafrost deposits and its degradation features," in Tenth International Conference on Permafrost-Resources and Risks of Permafrost Areas in a Changing World (Salekhard).

Tarnocai, C., Canadell, J. G., Schuur, E. A. G., Kuhry, P., Mazhitova, G., and Zimov, S. (2009). Soil organic carbon pools in the northern circumpolar permafrost region. Glob. Biogeochem. Cycles 23, GB2023. doi: 10.1029/2008GB003327

Tatusov, R. L., Koonin, E. V., and Lipman, D. J. (1997). A genomic perspective on protein families. Science 278, 631-637. doi: 10.1126/science.278.5338.631

Uhlirova, E., Santruckova, H., and Davidov, S. P. (2007). Quality and potential biodegradability of soil organic matter preserved in permafrost of Siberian tussock tundra. Soil Biol. Biochem. 39, 1978-1989. doi: 10.1016/j.soilbio.2007.02.018

Varga, J. J., Therit, B., and Melville, S. B. (2008). Type IV pili and the CcpA protein are needed for maximal biofilm formation by the Gram-Positive anaerobic pathogen Clostridium perfringens. Infect. Immun. 76, 4944-4951. doi: 10.1128/IAI.00692-08

Vernotte, C., Picaud, M., Kirilovsky, D., Olive, J., Ajlani, G., and Astier, C. (1992). Changes in the photosynthetic apparatus in the cyanobacterium Synechocystis Sp Pcc-6714 following light-to-dark and dark-to-light transitions. Photosyn. Res. 32, 45-57. doi: 10.1007/BF00028797

Vishnivetskaya, T. A., Petrova, M. A., Urbance, J., Ponder, M., Moyer, C. L., Gilichinsky, D. A., et al. (2006). Bacterial community in ancient Siberian permafrost as characterized by culture and culture-independent methods. Astrobiology 6, 400-414. doi: 10.1089/ast.2006.6.400

Waldrop, M. P., Wickland, K. P., White, R., Berhe, A. A., Harden, J. W., and Romanovsky, V. E. (2010). Molecular investigations into a globally important carbon pool: permafrost-protected carbon in Alaskan soils. Glob. Change Biol. 16, 2543-2554. doi: 10.1111/j.1365-2486.2009.02141.x

Walker, D. A., and Maier, H. A. (2008). Vegetation in the Vicinity of the Toolik Field Station, Alaska, No.28. Fairbanks: Institute of Arctic Biology.

Weijers, J. W. H., Schouten, S., Van Den Donker, J. C., Hopmans, E. C., and Sinninghe Damsté, J. S. (2007). Environmental controls on bacterial tetraether membrane lipid distribution in soils. Geochim. Cosmochim. Acta 71, 703-713. doi: 10.1016/j.gca.2006.10.003

Weimer, P. J., and Zeikus, J. G. (1979). Acetate assimilation pathway of Methanosarcina barkeri. J. Bacteriol. 137, 332-339.

Willerslev, E., Hansen, A. J., Binladen, J., Brand, T. B., Gilbert, M. T. P., Shapiro, B., et al. (2003). Diverse plant and animal genetic records from Holocene and Pleistocene sediments. Science 300, 791-795. doi: 10.1126/science.1084114

Willerslev, E., Hansen, A. J., Ronn, R., Brand, T. B., Barnes, I., Wiuf, C., et al. (2004). Long-term persistence of bacterial DNA. Curr. Biol. 14, R9-R10. doi: 10.1016/j.cub.2003.12.012

Yergeau, E., Hogues, H., Whyte, L. G., and Greer, C. W. (2010). The functional potential of high Arctic permafrost revealed by metagenomic sequencing, qPCR and microarray analyses. ISME J. 4, 1206-1214. doi: 10.1038/ismej. 2010.41

Yunker, M. B., Macdonald, R. W., Veltkamp, D. J., and Cretney, W. J. (1995). Terrestrial and marine biomarkers in a seasonally ice-covered arctic estuary integration of multivariate and biomarker approaches. Mar. Chem. 49, 1-50. doi: 10.1016/0304-4203(94)00057-K

Zhang, T. J., Frauenfeld, O. W., Serreze, M. C., Etringer, A., Oelke, C., McCreight, J., et al. (2005). Spatial and temporal variability in active layer thickness over the Russian Arctic drainage basin. J. Geophys. Res. Atmos. 110:D16101. doi: 10.1029/2004JD005642

Zheng, Y., Zhou, W., Meyers, P. A., and Xie, S. (2007). Lipid biomarkers in the Zoigê-Hongyuan peat deposit: indicators of Holocene climate changes in West China. Org. Geochem. 38, 1927-1940. doi: 10.1016/j.orggeochem.2007.06.012

Zimov, S. A., Davydov, S. P., Zimova, G. M., Davydova, A. I., Schuur, E. A. G., Chapin, F. S. et al. (2006). Permafrost carbon: stock and decomposability of a globally significant carbon pool. Geophys. Res. Lett. 33, L20502. doi: $10.1029 / 2006$ GL027484

Conflict of Interest Statement: The authors declare that the research was conducted in the absence of any commercial or financial relationships that could be construed as a potential conflict of interest.

Copyright (C) 2015 Coolen and Orsi. This is an open-access article distributed under the terms of the Creative Commons Attribution License (CC BY). The use, distribution or reproduction in other forums is permitted, provided the original author(s) or licensor are credited and that the original publication in this journal is cited, in accordance with accepted academic practice. No use, distribution or reproduction is permitted which does not comply with these terms. 